\title{
Tidsskriftets språkpoliti(kk)
}

Tidsskriftet har en veiledning til god språkbruk i retningslinjene for forfattere. «Redaksjonen ønsker å stimulere til en mer bevisst språkbruk i Tidsskriftets spalter»-gode og viktige intensjoner. I tillegg til generelle råd om bevisst norsk terminologi og setningsbygning finnes en kort, avsluttende henvisning til hvilke språkformer som er tillatt. For en artikkelforfatter skaper denne normen problemer.

Mange har en bevisst holdning til skriftspråket, basert på dialektbakgrunn, bosted og sosial tilknytning. Språket gir og uttrykker en identitet. Det norske språket er kjennetegnet av mange valgfrie former, nettopp fordi talemålet er så variert. I Tanums store rettskrivningsordbok er én av tre former valgfrie. Slik gis det rom for bevisste språklige valg innen visse rammer.

Redaksjonen har imidlertid tatt bort denne valgfriheten: «Vi ønsker å standardisere Tidsskriftets rettskrivning ...» «Ved valgfrie former har redaksjonen foretatt et valg: f.eks. likne, ikke ligne - frem, ikke fram.»

Redaksjonelt stoff skrevet av faste medarbeidere i Tidsskriftet kan selvsagt følge slike regler, dersom det er et mål i seg selv å begrense variasjonen. Mer problematisk er det når innsendte bidrag skal rettes med rød penn når rettskrivingsnormen er fulgt.

Dersom det er nødvendig å gjøre et redaksjonelt utvalg av tillatte former, bør dette gjøres med en viss konsekvens. En rimelig følge av dette vil være å bruke former som naturlig hører sammen.
«Likne» og «frem» er former som ikke hører hjemme i samme stil. Derfor er det vanskelig som manuskriptforfatter å forstå hvilken linje som egentlig føres, valgene oppleves som tilfeldige.

Som forfatter med avvikende forhold til konservative former som «frem» gjør det vondt for språksansen når en slik norm skal følges. «Frem» var i over 40 år ute av rettskrivningsnormen, men ble tatt inn igjen som sidestilt form i 1979. Når redaksjonen ønsker å legge språket tett opp til riksmålsformer, kjennes denne språklige tvangstrøya trang for noen av oss. Er redaksjonen villig til å la innsendte bidrag med godt og konsekvent norsk språk slippe språklig kokvask, eller skal vi begrenses til konservative former - i fremtiden?

\section{Ketil Størdal}

ketil.stoerdal@c2i.net

Barneavdelingen

Sykehuset Østfold Fredrikstad

1602 Fredrikstad

\section{Redaksjonen kommenterer:}

De mange sidestilte formene vi har i norsk er til både berikelse og bry. Valgmulighetene kan skape usikkerhet og problemer for skoleelever og for utlendinger som skal lære språket. Svenske og franske elever slipper å bruke tid på å finne ut hva som er «riktig» og hvilken form man absolutt ikke kan bruke - i ordboken er det ett svar. For nynorskens vedkommende foregår det et arbeid for å begrense antallet former. Mange mener mer normering vil kunne motvirke sosial stigmatisering og være et demokratisk virkemiddel.

De fleste aviser og tidsskrifter har interne språkregler for å sikre en enhetlig stil, kjent er Aftenpostens rettskrivningsordliste (1).

Dessuten er det arbeidsbesparende, siden de færreste skribenter greier å holde seg til samme form gjennom et helt manus og man på den måten slipper å telle og så velge den formen det er flest av.

Tidsskriftets ordliste består hovedsakelig av medisinske termer på norsk. Normalspråksnormeringen er resultatet av valg gjort over en lengre periode (2). Derfor kan det være at det finnes former «som ikke hører hjemme i samme stil». For tiden gjøres det undersøkelser av «normklynger» i avisspråket (3). Når vi vet mer om resultatet av dette arbeidet, kan det være på tide med en revisjon av ordlisten vår så den kommer til å bestå av «former som naturlig hører sammen». Hvilke det er, er også en diskusjon.

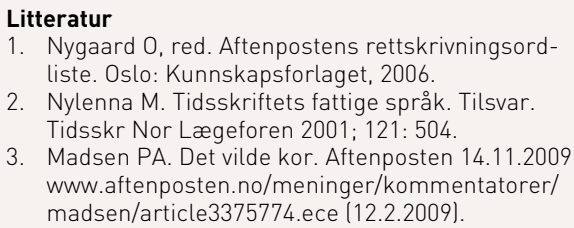

\section{Verdens korteste dikt?}

I Språkspalten i nr. 24/2009 belyser E. Arne Høiby de etymologiske forhold ved flere medisinske termer. Det er spennende lesning. Han krydrer artikkelen med et lite dikt, Lines on the antiquity of microbes, av Strickland Gillilan (1869-1954). Det sies at dette lenge har vært regnet som verdens korteste dikt. Det lyder:

\section{Adam}

Had 'em.

Tittelen var verken kursivert eller skrevet med fete typer, og det fikk meg et øyeblikk til å lure på om den var del av selve diktet. Overskriften kunne med fordel ha vært markert. Men det er av underordnet betydning.

Det er nok flere som vil bestride at dette fortsatt er verdens korteste dikt. I den kjente Oscar-belønnede dokumentarfilmen When we were kings (produsert i 1996 av Leon Gast), om boksekampen mellom
Muhammad Ali og George Foreman i Zaire i 1974, kommenterer journalisten George Plimpton ikke bare selve kampen (som førstnevnte for øvrig vant), men også andre hendelser i Muhammad Alis liv.

En av historiene dreier seg om den gang Ali holdt en tale for noe mellom $1000 \mathrm{og}$ 2000 sisteårsstudenter ved Harvard University i USA. Temaet var hvilke muligheter studentene hadde som han ikke hadde hatt. Talen skapte begeistring, og ved en anledning skal en student ha ropt til Muhammad Ali: «Give us a poem!» Ifølge Plimpton senket det seg en stillhet over forsamlingen før Ali, etter å ha tenkt seg litt om, svarte: «Me, we.» Det var det hele. Disse to korte ordene forsterket den allerede gode stemningen i forsamlingen. George Plimptons beskrivelse er verdt å høre (et utsnitt fra When we were kings finnes på YouTube). Plimpton avslutter fortellingen med å si at han i sin begeistring hadde tatt til orde for at dette fra nå av burde regnes som verdens korteste dikt og at han hadde foreslått at det måtte tas inn i Bartlett's familiar quotations. Selv forsøkte jeg - i min begeistring å finne ut om Plimpton hadde nådd frem med forslaget sitt. Det gjorde han nok ikke. Mohammad Ali er ikke tatt inn blant poetene i Bartlett's. Men googler man «world's shortest poem» (som gir over 90000 treff), finner man flere som mener at dette må være verdens korteste poem:

$$
\begin{aligned}
& \mathrm{Me}, \\
& \text { we! }
\end{aligned}
$$

Det rimer. Det er enkelt. Og det er flott!

\section{Trygve Nissen}

trygve.nissen@unn.no

Psykiatrisk senter for Troms $\emptyset$ og omegn

Universitetssykehuset i Nord-Norge

9291 Tromsø 